\title{
EFFICIENCY IN RELIGIOUS WORK
}

\author{
By William H. Allen, Ph.D.,
}

Secretary, Bureau of Municipal Research, New York City.

The money changers were not chided, exhorted, vituperated or petitioned; they were driven from the temple. There were probably those among them who were shocked at the spectacle of religious work directing itself to "politics" and to "sensational reform." But the public which looked on received more inspiration from this applied religion than from a thousand sermons on Christian citizenship delivered under the auspices of the money changers.

The efficiency of Christ's ministry-as distinct from its inspirational power-has received too little attention. Sometimes it seems as if those outside church organizations read the parables with more reverence and greater appreciation than the very expounders of the Gospel. The rigid standard with which the alleged irreligious man measures the avowed religious man is one that could advance religious work incalculably if only religious workers would adopt it for themselves. That measure is the efficiency test-the consistency test-the setting side by side of pretense and practice, faith and work, effort expended and results obtained. The application of this efficiency test to Christ's life and teaching gives that teaching an ever higher place in the lives of men. If religions work is losing devotees, if the Church is losing influence, it is because leader and follower fail to apply the efficiency test to their living, their teaching, their parish work, their Christian citizenship.

New York City pays liberal salaries to hundreds of preachers. In addition, millions are given for $\mathrm{Y}$. M. C. A. buildings, missions, institutional church work, parish houses, etc. In exchange for these gifts, preachers and pastors are to preach the gospel and to organize the forces of righteousness. To the pleasure given by preaching, well-to-do audiences at least apply result tests; if the sermons are uninteresting, the preacher is asked to find another post. To the preacher's personality definite tests are applied; if he is uncongenial, unrefined, uninformed as to "the world's ways" of speaking and acting, he is not retained in a fashionable church. 
He may be forgiven if a poor manager, and provided with assistants who can organize clubs and collect funds. But the results of the preacher's sermons upon his auditors, the results of his week-day efforts upon his parish, the results of his ministry upon the neighborhood of his church are not set side by side with his opportunity, and the church deficit computed. If you ask one hundred prominent religious workers what the church deficit is, they will reply "About $\$ 2,500$," or "We came out even." Wherever efficiency tests are applied to religious work, deficit means not the difference in money between receipts and disbursements but the difference in results between the moral infuence the church might have exerted and the infuence actually exerted.

The need for efficiency tests may be indicated by comparing the thousands of religious workers who are paid to give their entire time to inspirational, gospel service, with the number who are paid to give their entire time to driving out money changers and preventing their return. I spoke recently to a group of pastors on the subject "Social Injuries Caused by Inefficient Government." They had felt that the subject would be more attractive if written "Institutional Vice and Public Officials." I explained to them why I did not wish to speak of vice: that little good ever came of discussing vice unless the causes of vice were aimed at. If vice is regarded as in a large measure due to social, industrial and governmental conditions, then the intelligent, efficient way to reach it is to correct the government and industry of which vice is an unfortunate product. The combined salaries of these pastors, not including any other salaries or church expenses, aggregated about $\$ 100,000$. The salaries of all the pastors in their city exceeded $\$ 250,000$. This sum was gladly given by their city to insure a constant flow of religious light and inspiration. But not one salary is paid in that city to insure a constant testing of the results upon the community of the constant ministry of this regiment of earnest workers.

After a Sunday evening given to warnings against vice and appeals for a life of chastity, young people go out upon the streets where policemen grow rich by abetting and protecting vice. Youns girls go into homes that are worse than the deplorable factory conditions of the week to follow. Overcrowding, underventilation, uncleanness bring them up. Their minds cannot hold, even if they receive, the message given at church because their bodies are weak 
and crave stimulant, drug or other excitation. A beautiful sermon, aided by electric lights, will help the tenement girl to live an open, beautiful life. Perhaps, if compelled to choose, the sermon would be better than the electric lights, but there is reason to doubt it. Fortunately, both are possible if pastors will only apply result tests to their work.

The ignorant mother is told repeatedly by newspapers and nurses that her baby dies not because a chastening Providence wishes to touch her heart or hold her hand, but because milk dealers and dairymen are permitted by lax officials-for pay or favor or easeto sell impure milk. Shop girls know that the tempter most to be feared is not in their hearts but in their working and living conditions. Efficiency in religious leadership requires that these working and living conditions be made fit to work in and to live in. Christ never asked a throng to listen to His message when hungry, in a storm, in a tumult or in the presence of active evil forces. It is inconceivable that $\mathrm{He}$ would dismiss a congregation into a saloon or into streets leading directly to saloons violating Sunday laws, liquor laws, the laws of health and of decency. It is inconceivable that $\mathrm{He}$ would avoid such subjects as misgovernment, preventable sickness, deficient school facilities, unclean streets, police protection for brothels and gambling dens, on the ground that they were political, not religious.

We can never know what it has cost humanity that Christ's teachings have been made to bolster up such doctrines as that good intention or one step in the right direction will be accepted in lieu of effort and achievement in proportion to opportunity. The parable of the lost sheep, like that of the talents, has been perverted to mean that one is not strictly accountable for the efficient administration of his Christian effort. As a matter of fact, there is nothing in this or any other parable to warrant the belief that it would have been worth while for any shepherd to spend time looking for one lost sheep known to be at the west, if the same effort might have recovered ten lost sheep known to be in the east. The particular case in question was never intended to place in the balance one unit of any kind, whether sheep, dollar, soul or week's work, and teach the untruth that this one unit is worth ninety-nine units of the same kind. The steward who had the use of one talent was condemned, not for hiding his talent, not for failing to bring back 
some return, not because he did not try, but because he did not earn with his opportunity at least the current rate, one hundred per cent. The virgins were not permitted to focus attention on their lamps, but were rather censured for having no oil at the particular time when it was needed. The prodigal son was feted not for running away, not for repentance, but in spite of the older brother's goodness fallacy, for the definite act of returning. Miracles were performed, not to show wonders but to meet need adequately, feed all of the out-door congregation, cure palsy, raisc the dead, not turn him over in his grave. Dives went into hell, not in that direction or to a sermon about it.

Efficiency tests are now applied to many branches of religious work; they can be extended to all branches. Medical missionaries must know physiology and medicine. They are not chosen for their intention but for their ability to do good. Training schools exist for deaconesses and parish visitors in many cities, who are chosen not because they are good but because they have shown ability to get good results. Preachers must show ability to talk well. Tests of talking are easy to apply. So it is easy to test ability to get together clubs of boys and girls. Whether money enough is contributed, whether each member is doing his share, can and should be found out; it is just as easy to test the work of the Church as an organized body of Christian citizens. If Christian citizens who pass the contribution plate own premises that are being used for disreputable and illegal purposes, the fact can be ascertained by them and by their fellow religious workers. If, within the district of which the church is a center, milk that poisons is being sold, or if streets are dirty and hospitals mismanaged, the fact can be positively ascertained and the conditions corrected. If government officials are padding payrolls, wasting taxes, granting special privileges or otherwise manufacturing dishonesty or criminality, the fact can be proved and stopped. If children are improperly taught at school, and turned out physically, mentally and industrially unfit to do their part as Christian citizens, the fact can be ascertained positively and the conditions corrected.

The American Sabbath is fast losing ground; young people do not attend church as did their parents; even the institutional Church has failed to stem the tide of growing irreligion; young men of larga capacities are less willing than formerly to enter the ministry; it is 
increasingly difficult to obtain funds for maintaining not only missions but even old established churches. Are these statements true? I do not know. They are solemnly affirmed by leaders in religious work. Whether true or not, however, it is a most serious matter, deserving the kind of investigation that would be given a railroad management whose dividends decreased or whose road bed was greatly in need of repair.

Efficiency tests of religious work have not hitherto been applied sufficiently, because religious leaders have not felt responsible for unsanitary living and working conditions or for misgovernment that causes distress and vice and inability to comprehend and heed the gospel message. The men and women who are identified with religious work could abolish misgovernment if they would work together for definite visible ends in their communities. When they fail so to work together their religious work is inefficient. Whether they do it and what community work is left undone can be positively learned if they will look for conditions that make Christian living unnecessarily difficult for the strong and impossible for the weak.

If the religious worker cares to know about the efficiency of his church or mission or Christian Endeavor society, he will find such questions as the following helpful: Are the streets clean? Are milk shops properly inspected? Do weights and scales defraud the poor of the parish? Are demoralizing influences unchecked or unattacked? Is he exerting any appreciable influence to make the public opinion of the good who desire good government stronger than the private opinion of evil men who desire bad government?

These essentials of the efficiency test are simple and can be applied by the intelligent worker to himself, to the society of which he is a responsible officer, to the church and to the allied Christian forces of his community. The elements of this test are: Desire to know ; unit of inquiry ; account ; comparison ; subtraction ; percentage; classification; summary. All Sunday-schools have weekly, monthly and annual reports. In most instances these reports show whether the Sunday-school is growing larger or smaller. There is no reason why the same method of analysis should not be applied to the influence of that Sunday-school and to children not attending who ought to attend, to parents not interested who ought to be interested, to evils existing in its neighborhood that ought not be permitted to exist, to community work not done that ought to be done. 
The religious world needs as much as does the business world to have the desire to know what are the results of its efforts. The unit of inquiry depends upon what the church or church worker is trying to do. Any effort which has no definite purpose and has no unit of inquiry will not be of serious consequence. There are so many efforts that are not yet compared with results and so many units of inquiry requiring religious work that church bookkeepers will be kept answering them for some time to come. If any religious worker has difficulty in selecting the units that should be counted first, let him make a list of the things that worry him, or seem to worry his co-workers or parishioners. If the religious worker is not worrying at all and has no unanswered questions in his mind, that is a pretty sure sign that he is not doing his work efficiently. Goodness, spirituality, religious fervor, should not be permitted to manufacture evil or to waste opportunity to do good. Efficiency tests prevent a worker from undertaking tasks to which he is unfitted; efficiency tests use to the utmost, character, good intention and religious fervor by adjusting burden to capacity and by requiring effort commensurate with opportunity. 